いて 4 人の講師によりパネルディスカッションを行っ た。.さらに第 7 回例会 $(60$ 年 3 月 29 日）では, 研究者 の立場から筑波大学 原田氏，いす心゙ 丸井氏(副部会長) による講演会を行った。

第 8 回例会は, 学会の第 25 回大会の行事の一環とし て“ハイテク時代における使いやすさ”をテーマに，各 分野より 4 人のパネリストによるシンポジウムを行っ た. 第 9 回例会は 60 年 9 月 30 日, 機械工業デザイン賞 受賞社のなかから，特に人間工学的処理について高く評 価された 3 社（オリンパス工業, 帝国デンタル，日本ビ クター）の開発担当者を講師として，パネルディスカッ ションを行った.

例会は年 4 回行うことにしており，今年度としては第 10 回として “動剖計測について”, 第 11 回として “G マ 一ク商品における人間工学的問題”をテーマに, 研究部 会を開催する予定である.

以上のでとく，研究例会により着々と成果をあげてき ているが，対象とする問題，課題に対して対処すべき事

\section{ヒトのはかりかた研究部会}

本部会は 昭和 60 年度に発足し, 5 月 9 日第 1 回の会 合が国立京都国際会館で 開かれた. 発起人は斉藤 進 (産業医学総合研究所), 徳田哲男 (東京都老人総合研 究所), 野呂影勇 (産業医科大学) 飞筆者が加わり, 形 式上部会長を筆者が引き受けさせていただいたが，幹事 を徳田先生が担当し，実質は発起人の共同に上り運営さ れる.

この部会を語るには，その前身である検査計測部会へ さかのぼる必要がある．初めは関東支部の分科会として 飯山雄次, 林 喜男の両先生の御支援のもと, 野呂先生 と筆者で運営したが,さらに部会としての活動を行い, その間, シンポジウム, 研究会, 会誌特集などを企画さ せていただいた，名前の由来からわかるように，工程に おける管理とか検查における人間工学的な問題の研究と いうのが主眼であったが，会合を重ねるうちにもっと広 く人間工学における計測全般を取りあげるべきではない かというととになり，検查より計測に重点がおかれるよ うになった。

では，人間工学における計測とは何かというと，てれ がわかったようでわからない，工学として計測は不可欠 であり, しかも多くの研究がデータの取得を中心にして
柄が多く，今後ますます活動を活発に充実していかねば ならないので，なお多数の会員諸兄の参加，支援をお願 いする次第である．以下に現在の部会役員，および事務 局を記すので, 御連絡下さい.

$$
\begin{aligned}
& \text { 部 会 長 森本眞佐男（育英工専） } \\
& \text { 副部会長 菊池 安行 (千葉大) } \\
& \text { " 丸井一郎 (いすぐ) } \\
& \text { 幹事 内田 謙 (女子美大) } \\
& \text { " 寿美田与市 (東京芸大) } \\
& \text { " 堀野 定雄（神奈川大） } \\
& \text { " 肝付 邦憲 (労働科学研) } \\
& \text { " 古賀 唯夫 (九州芸工大) } \\
& \text { " 出口 良生（筑波大） }
\end{aligned}
$$

事 務 局 $\bar{\top} 211$ 川崎市中原区上小田中 1015 冨士通株式会社 スペースデザイン部エルゴ ノミックス課内

電話 044-777-1111（ex. 2-2562）

担当 上田, 岩崎

\title{
矢野 宏
}

行われるとなると，人間工学即計測というととになり， 人間工学的なものを対象とした計測の一部門が人間工学 というふうにもなりかねない。しかし，てれではどてか おかしいので, 検查計測部会の最終時期には人間工学と 計測ということが検討の中心となった．筆者の独断も交 えていえば，人間工学的な対象を計測する場合の計測の 共通的な方法論をつくることと定義されたように思う。 このような考光のもとで，炤和 59 年度の大会において シンポジウムが行われたが, 多くの方々が関心をもって おられるととが明らかになった。しかも傠議の過程か ら, 人間工学的なデータの信頼性の確保について, 多く の方々が悩みをもっておられることもわかり，ての種の 部会を存続させる必要性在徳田, 野呂の雨先生が強調さ れ新しい部会の発足となった。

このようなととから, 前記シンポジウムで提起された 問題は新しい部会の中心的な課題となると思われるの で，再録する。

（1）人間工学的な研究結果は一義的でないが，その適 切さをいかに評価するか。

（2）実験を行うためには必ず強制負荷が行われるが， 強制負荷方法とその正しさをいかにして求めたらよ 
いか.

（3）実験は常に経時的に行われ, 経時的変化には対象 の変化と, 計測方法の変化が含まれるが, そのデー タをいかに解析したらよいか。

（4）経時的変化と関連して，動機づけによるデータの 変化, 対象の変化など, データの再現性の確保なら びにその評価をいかに行うか.

（5）不可避的なものとしての個体差の求め方と個体差 の扱い方をいかにすべきか.

これらの問題は, 人間工学の諸領域においてはそれぞ れ専門的に解決されているかもしれないが，それらを共 通化させて, 計測の部分のみを取りだして研究し, デー タの信頼性を確保するための方法を探そうというのが,
この部会の目的ではないかと思う。

具体的な部会の運営方法としては,メンバーより問題 提起をしていただき，そてから共通的な問題を探しだす 作業を行うことと, 人間工学関連の諸計測器機のメーカ と協力してモデル実験を行い，それを全員で検討するて とから，共通的な方法論をつくるということにした。

現在, 第 3 回の会合を終了したところであり, 医学, 衣服, 体育, 計測などの広い分野から約 20 名のメンバ 一となっている. さらに, 竹井機器工業偐, 侏ナックが 参加して, 実験への協力を開始してくれている. 発起人 よりの話題提供, メンバーからの問題提起など, 活発な 部会となりそうなので楽しみにしている。

\section{水中における人間活動にかんする 研究の現状と今後の課題}

宇宙，原子才とともに今世紀の 3 大巨大科学のひとつ に数えられる海洋の研究は, 遅々として進んでいない. その大きな理由のひとつは，水中の人間活動自体がけっ して目新しいものでないことにあろう，潜水に関する記 述は，古くはローマ時代に遡り，紀元前 400 年，アレキ サンダー大王が海戦の折に自ら水中に潜ったてとがあげ られ，また，中国の史書〔魏志倭人伝〕には我国の海女 の記載がみられるほどに，大昔から海はわれわれの日常 の生活に密着した存在であり，欲するままに接触が可能 であった。このことが海を特別視する根拠に久け，一線 を画した実験研究に迫力を感じない原因ではあるまい か. 昭和 44 年から実施しているシートピア計画にしろ, 物語“浦島太郎”の内容に酷似しており，新しい画期的な 研究であるという印象を受けない，陸上の資源を開発・ 消費しつくした人類の未来を支える豊富な資源の，次な る候補地は海洋であるという羿識を今いちど肝に銘じて おくととが必要である。

戦争が科学の進歩をもたらすというが，てれは過去の 話であり，今後は戦争という過程を経るまでもなく，す すんで平和目的に科学龺応用する見識をもつことが必要 であろう。

さて，わが日本人間工学会が時代を先取りして海洋の 研究に学際的展望をもって部会活動をしようとする動き は過去にもあり，それなりに成果もあがっている。しか しながら，最近の低調ぶりは我国の将来にもけっしてプ ラスにならないことを認識し，あえて活性化のために

\section{中山英明}

も，部会の新設と新進気鋭の士の参加を呼びかけるもの である.いうまでもなく，海洋そのものは我々の住む陸 上の環境とは著しく異なり, いわば異常環境であり,す べての環境要因が違っている，たとえば，水中であると とから水の浮力が働き, 重力が減少し, 極端な場合は逆 に相当の浮力が作用する. 媒体が水であることから, 温 熱環境についても空気環境とは比較にならない，てのよ うな相違点を数えあげればきりがないが，それほど異な った環境での人間活動が要請される時代にめぐりあい, しかも人間工学を志した者が集まって, それぞれの専門 分野からの学際研究在成し遂げることの意義は重大であ る。

第一にあげられる研究課題は水中生理学り研究進展で あろう.人間活動を根底にする以上, 当然のことであ り, 高死下における生理学的変化をまず追求することが 求められる.この際, 問題とされるのは人間自体は陸上 生活を基調としており，家庭を中心とした社会生活を営 んでいることで，たとえば宇宙船に乗りこんでも，任務 を終えた後は再び陸上に返ることが前提である. 同様 に，海中に居住したとしても，そのあと必ず陸上へ返る ことになり, せっかく高圧環境に適志し身体機能は高圧 人間になりきっていても，また時間をかけて大気圧空気 環境に再適灾しなければならなくなるととである.

第二に, 環境条件の設定である. 生理学的研究から導 きだされたデータをもとに環境づくりをするととであ る.たえず呼吸ガスを供給し，適切な温度環境を維持し 